\title{
The Significance of Long-chain Fatty Acid Composition and Other Phenotypic Characteristics in Determining Relationships Among Some Pichia and Candida Species
}

\author{
By BENNIE C. VILJOEN, * JOHAN L. F. KOCK AND TREVOR J. BRITZ \\ Department of Microbiology, University of the Orange Free State, PO Box 339, \\ Bloemfontein 9300, South Africa
}

(Received 9 December 1987)

\begin{abstract}
The long-chain fatty acid compositions of 22 species of Candida were determined, and compared with the fatty acid compositions of 10 species of the genus Pichia that contain coenzyme Q9. The long-chain fatty acid results were also compared with other phenotypic criteria (i.e. assimilation of carbon sources, coenzyme $Q$ type, $G+C$ content and proton magnetic resonance spectra) in order to establish possible anamorph/teleomorph relations. Close correlations were found between known perfect/imperfect states. The results suggest that $C$. cacao $i$ and $P$. farinosa, and C. maltosa and $P$. etchellsii, also have anamorph/teleomorph relationships.
\end{abstract}

\section{INTRODUCTION}

In previous papers (Viljoen et al., 1986a, 1987) we have shown long-chain fatty acid analysis to be valuable in determining relations between teleomorphic and anamorphic yeasts. In this study, we investigated the relationships between species of the genus Pichia containing coenzyme Q type 9, and species of the genus Candida. Several possible anamorph/teleomorph relations are discussed on the basis of long-chain fatty acid compositions, coenzyme $Q$ systems, $\mathrm{G}+\mathrm{C}$ values and other phenotypic characteristics (i.e. carbon and nitrogen assimilation, and growth in vitamin-free media and at $37^{\circ} \mathrm{C}$ ). A new comparative model for determining anamorph/teleomorph relations is also demonstrated.

\section{METHODS}

Strains. Twenty-two Candida and ten Pichia species were examined (Table 1).

Cultivation. Stock cultures were maintained on yeast extract/malt extract (YM) (Wickerham, 1951) slants. The yeast strains were cultured under standard conditions in $40 \mathrm{ml}$ of a liquid medium containing $80 \mathrm{~g}$ glucose (Merck) $1^{-1}$ and $6.7 \mathrm{~g}$ yeast nitrogen base (YNB: Wickerham, 1951) $\mathrm{l}^{-1}$. The harvesting and time of growth were as described in previous papers (Viljoen et al., 1986b; Kock et al., 1985).

Extraction of fatty acids, preparation of methyl esters and gas chromatography. These procedures were described in detail by Viljoen et al. (1986a) and Koch et al. (1985).

The long-chain fatty acid composition of some species of Pichia (i.e. $P$. carsonii, $P$. etchellsii, $P$. farinosa, $P$. ohmerii and $P$. sorbitophila) are reproduced from Muller et al. (1987). The relative mean percentages are shown in Table 1 and Fig. 1.

Carbon-source assimilation. The assimilation results were obtained from Barnett et al. (1983) and Kreger-van Rij (1984) and are illustrated in Fig. 1. 'Positive', 'variable', and also descriptions such as 'seldom positive' or 'rarely positive', are indicated by black blocks while negative properties are indicated by open spaces.

Numerical analyses. Analyses were performed by comparing groups comprising 29 characters (assimilation of 26 carbon sources; nitrate utilization; growth in vitamin-free medium and at $37^{\circ} \mathrm{C}$ ). Both matched and unmatched pairs were equally weighted using the simple matching coefficient of association of Sokal \& Michener (Sokal \& Sneath, 1963). A dendrogram (Fig. 1) was prepared by single linkage cluster analysis.

The different Candida and Pichia species were positioned in Fig. 1 according to the results indicated on the horizontal and vertical scales. Numbers were allocated to each species to aid clarity of presentation. 
Table 1. Mean percentage long-chain fatty acid composition of the species representing Candida and Pichia

Values are the means of three repetitions. Fatty acids are designated as number of carbon atoms : number of double bonds.

\begin{tabular}{|c|c|c|c|c|c|c|c|c|c|c|}
\hline Group & Species & Strain no.* & $\mathrm{C} 14: 0$ & $\mathrm{C} 14: 1$ & $\mathrm{C} 16: 0$ & $\mathrm{Cl} 16: 1$ & $\mathrm{C} 18: 0$ & $\mathrm{C} 18: 1$ & $\mathrm{C} 18: 2$ & $\mathrm{C} 18: 3$ \\
\hline I & C. oregonensis & CBS 5036 & $0 \cdot 2$ & $0 \cdot 7$ & $15 \cdot 2$ & $14 \cdot 8$ & $1 \cdot 0$ & $23 \cdot 7$ & $38 \cdot 1$ & $6 \cdot 3$ \\
\hline IIA. & $\begin{array}{l}\text { C. catenulata } \\
\text { C. santamariae } \\
\text { C. zeylanoides } \\
\text { C. glaebosa } \\
\text { P. stipitis } \\
\text { C. shehatae }\end{array}$ & $\begin{array}{l}\text { CBS } 564 \\
\text { CBS } 4515 \\
\text { CSIR-Y979 } \\
\text { CSIR-Y581 } \\
\text { CSIR-Y633 } \\
\text { CSIR-Y492 }\end{array}$ & $\begin{array}{l}0 \cdot 4 \\
0 \cdot 1 \\
0 \cdot 1 \\
0 \cdot 2 \\
0 \cdot 2 \\
0 \cdot 9\end{array}$ & $\begin{array}{l}0 \cdot 6 \\
0 \cdot 1 \\
0 \cdot 1 \\
0 \cdot 1 \\
0 \cdot 1 \\
0 \cdot 1\end{array}$ & $\begin{array}{l}14 \cdot 0 \\
11 \cdot 2 \\
10 \cdot 0 \\
13 \cdot 0 \\
20 \cdot 3 \\
16 \cdot 9\end{array}$ & $\begin{array}{r}9 \cdot 8 \\
8 \cdot 3 \\
2 \cdot 7 \\
4 \cdot 0 \\
10 \cdot 3 \\
9 \cdot 4\end{array}$ & $\begin{array}{l}2 \cdot 4 \\
1 \cdot 2 \\
1 \cdot 7 \\
3 \cdot 7 \\
4 \cdot 8 \\
4 \cdot 8\end{array}$ & $\begin{array}{l}41 \cdot 4 \\
43 \cdot 7 \\
43 \cdot 8 \\
33 \cdot 4 \\
36 \cdot 2 \\
36 \cdot 7\end{array}$ & $\begin{array}{l}27 \cdot 3 \\
31 \cdot 3 \\
29 \cdot 4 \\
33 \cdot 1 \\
26 \cdot 2 \\
23 \cdot 8\end{array}$ & $\begin{array}{r}1 \cdot 8 \\
3 \cdot 3 \\
10 \cdot 4 \\
12 \cdot 8 \\
0 \cdot 9 \\
2 \cdot 1\end{array}$ \\
\hline & $\begin{array}{l}\text { Mean } \\
\text { Standard deviation }\end{array}$ & & $\begin{array}{l}0 \cdot 32 \\
0 \cdot 31\end{array}$ & $\begin{array}{l}0 \cdot 18 \\
0 \cdot 20\end{array}$ & $\begin{array}{r}14 \cdot 23 \\
3 \cdot 81\end{array}$ & $\begin{array}{l}7 \cdot 41 \\
3 \cdot 24\end{array}$ & $\begin{array}{l}3 \cdot 10 \\
1 \cdot 56\end{array}$ & $\begin{array}{r}39 \cdot 20 \\
4 \cdot 36\end{array}$ & $\begin{array}{r}28 \cdot 50 \\
3 \cdot 43\end{array}$ & $\begin{array}{l}5 \cdot 21 \\
5 \cdot 06\end{array}$ \\
\hline IIB. & $\begin{array}{l}\text { C. rugosa } \\
P . \text { scolyti } \\
\text { C. silvicultrix } \\
\text { C. entomophila } \\
\text { C. dendronema } \\
\text { P. mexicana }\end{array}$ & $\begin{array}{l}\text { CSIR-Y299 } \\
\text { CBS } 4802 \\
\text { CSIR-Y481 } \\
\text { CSIR-Y479 } \\
\text { CBS } 6270 \\
\text { CBS } 7066\end{array}$ & $\begin{array}{l}0 \cdot 3 \\
0 \cdot 2 \\
0 \cdot 2 \\
0 \cdot 2 \\
0 \cdot 1 \\
0 \cdot 1\end{array}$ & $\begin{array}{l}0 \cdot 2 \\
0 \cdot 1 \\
0 \cdot 1 \\
0 \cdot 1 \\
0 \cdot 2 \\
0 \cdot 1\end{array}$ & $\begin{array}{l}14 \cdot 5 \\
17 \cdot 7 \\
15 \cdot 8 \\
12 \cdot 5 \\
27 \cdot 8 \\
25 \cdot 9\end{array}$ & $\begin{array}{l}3 \cdot 8 \\
4 \cdot 8 \\
3 \cdot 6 \\
3 \cdot 8 \\
8 \cdot 3 \\
9 \cdot 5\end{array}$ & $\begin{array}{l}0 \cdot 4 \\
3 \cdot 2 \\
2 \cdot 3 \\
3 \cdot 2 \\
4 \cdot 4 \\
2 \cdot 0\end{array}$ & $\begin{array}{l}55 \cdot 0 \\
40 \cdot 3 \\
41 \cdot 9 \\
49 \cdot 3 \\
35 \cdot 3 \\
37 \cdot 5\end{array}$ & $\begin{array}{l}20 \cdot 3 \\
27 \cdot 4 \\
20 \cdot 5 \\
26 \cdot 0 \\
15 \cdot 3 \\
18 \cdot 9\end{array}$ & $\begin{array}{r}3 \cdot 6 \\
6 \cdot 4 \\
10 \cdot 5 \\
3 \cdot 1 \\
5 \cdot 1 \\
4 \cdot 1\end{array}$ \\
\hline & $\begin{array}{l}\text { Mean } \\
\text { Standard deviation }\end{array}$ & & $\begin{array}{l}0 \cdot 18 \\
0 \cdot 07\end{array}$ & $\begin{array}{l}0 \cdot 13 \\
0 \cdot 05\end{array}$ & $\begin{array}{r}19 \cdot 03 \\
6 \cdot 31\end{array}$ & $\begin{array}{l}5 \cdot 63 \\
2 \cdot 59\end{array}$ & $\begin{array}{l}2 \cdot 58 \\
1 \cdot 36\end{array}$ & $\begin{array}{r}43 \cdot 21 \\
7 \cdot 50\end{array}$ & $\begin{array}{c}21 \cdot 4 \\
4 \cdot 50\end{array}$ & $\begin{array}{l}5 \cdot 46 \\
2 \cdot 73\end{array}$ \\
\hline IIC. & $\begin{array}{l}\text { C. quercitrusa } \\
P . \text { ohmerii } \\
\text { C. tenuis } \\
\text { C. guilliermondii } \\
P . \text { guilliermondii }\end{array}$ & $\begin{array}{l}\text { CBS } 4412 \\
\text { CBS } 568 \\
\text { CSIR-Y566 } \\
\text { CSIR-Y47 } \\
\text { CBS } 2030\end{array}$ & $\begin{array}{l}0 \cdot 3 \\
0 \cdot 2 \\
0 \cdot 3 \\
0 \cdot 1 \\
0 \cdot 1\end{array}$ & $\begin{array}{l}0 \cdot 1 \\
0 \cdot 1 \\
0 \cdot 1 \\
0 \cdot 1 \\
0 \cdot 1\end{array}$ & $\begin{array}{l}19 \cdot 9 \\
12 \cdot 3 \\
13 \cdot 9 \\
18 \cdot 5 \\
19 \cdot 1\end{array}$ & $\begin{array}{r}3 \cdot 7 \\
4 \cdot 7 \\
11 \cdot 5 \\
8 \cdot 3 \\
9 \cdot 6\end{array}$ & $\begin{array}{l}2 \cdot 0 \\
4 \cdot 4 \\
3 \cdot 2 \\
5 \cdot 8 \\
4 \cdot 6\end{array}$ & $\begin{array}{l}53 \cdot 2 \\
63 \cdot 7 \\
54 \cdot 8 \\
54 \cdot 7 \\
50 \cdot 1\end{array}$ & $\begin{array}{l}14 \cdot 6 \\
12 \cdot 0 \\
11 \cdot 9 \\
10 \cdot 6 \\
14 \cdot 3\end{array}$ & $\begin{array}{l}4 \cdot 6 \\
2 \cdot 4 \\
3 \cdot 8 \\
1 \cdot 5 \\
1 \cdot 8\end{array}$ \\
\hline & $\begin{array}{l}\text { Mean } \\
\text { Standard deviation }\end{array}$ & & $\begin{array}{l}0 \cdot 20 \\
0 \cdot 10\end{array}$ & $\begin{array}{l}0 \cdot 10 \\
0 \cdot 00\end{array}$ & $\begin{array}{r}16 \cdot 75 \\
3 \cdot 38\end{array}$ & $\begin{array}{l}7 \cdot 56 \\
3 \cdot 29\end{array}$ & $\begin{array}{l}4 \cdot 00 \\
1 \cdot 44\end{array}$ & $\begin{array}{r}55 \cdot 30 \\
5 \cdot 06\end{array}$ & $\begin{array}{r}12.68 \\
1 \cdot 71\end{array}$ & $\begin{array}{l}2 \cdot 82 \\
1 \cdot 33\end{array}$ \\
\hline III & $\begin{array}{l}\text { P. haplophila } \\
\text { C. maltosa } \\
\text { P. etchellsii } \\
\text { Mean } \\
\text { Standard deviation }\end{array}$ & $\begin{array}{l}\text { CBS } 2028 \\
\text { CBS } 5611 \\
\text { CBS 2011T }\end{array}$ & $\begin{array}{l}0 \cdot 2 \\
0 \cdot 2 \\
0 \cdot 2 \\
0 \cdot 20 \\
0 \cdot 00\end{array}$ & $\begin{array}{l}0 \cdot 3 \\
0 \cdot 2 \\
- \\
0 \cdot 16 \\
0 \cdot 15\end{array}$ & $\begin{array}{l}17 \cdot 1 \\
16 \cdot 6 \\
14 \cdot 0 \\
15 \cdot 90 \\
1 \cdot 66\end{array}$ & $\begin{array}{l}7 \cdot 8 \\
8 \cdot 7 \\
7 \cdot 8 \\
8 \cdot 10 \\
0 \cdot 51\end{array}$ & $\begin{array}{l}1 \cdot 5 \\
4 \cdot 6 \\
2 \cdot 9 \\
3 \cdot 00 \\
1 \cdot 55\end{array}$ & $\begin{array}{l}26 \cdot 6 \\
28 \cdot 9 \\
31 \cdot 1 \\
28 \cdot 86 \\
2.25\end{array}$ & $\begin{array}{r}46 \cdot 8 \\
40 \cdot 7 \\
43 \cdot 7 \\
43 \cdot 73 \\
3 \cdot 05\end{array}$ & $\begin{array}{l}- \\
- \\
- \\
- \\
-\end{array}$ \\
\hline IV & $\begin{array}{l}\text { C. schatavii } \\
\text { P. sorbitophila } \\
\text { C. cacaoi } \\
\text { P. farinosa } \\
\text { C. blankii } \\
\text { P. carsonii } \\
\text { C. hydrocarbofumarica }\end{array}$ & $\begin{array}{l}\text { CBS } 6452 \\
\text { CBS 7064T } \\
\text { CBS 202 } \\
\text { NRRL Y-7553 } \\
\text { CBS 1898 } \\
\text { NRRL Y-4275 } \\
\text { CBS 6734 }\end{array}$ & $\begin{array}{l}0 \cdot 2 \\
0 \cdot 2 \\
0 \cdot 1 \\
0 \cdot 1 \\
0 \cdot 1 \\
0 \cdot 1 \\
0 \cdot 2\end{array}$ & $\begin{array}{c}0 \cdot 1 \\
- \\
0 \cdot 1 \\
- \\
- \\
- \\
0 \cdot 1\end{array}$ & $\begin{array}{r}18 \cdot 7 \\
13 \cdot 3 \\
9 \cdot 3 \\
9 \cdot 4 \\
16 \cdot 2 \\
16 \cdot 3 \\
16 \cdot 8\end{array}$ & $\begin{array}{l}2 \cdot 6 \\
3 \cdot 6 \\
3 \cdot 0 \\
4 \cdot 0 \\
2 \cdot 4 \\
2 \cdot 7 \\
3 \cdot 0\end{array}$ & $\begin{array}{r}10 \cdot 4 \\
0 \cdot 6 \\
0 \cdot 9 \\
1 \cdot 0 \\
3 \cdot 7 \\
2 \cdot 4 \\
8 \cdot 5\end{array}$ & $\begin{array}{l}48 \cdot 4 \\
69 \cdot 3 \\
53 \cdot 7 \\
56 \cdot 3 \\
49 \cdot 2 \\
51 \cdot 7 \\
49 \cdot 8\end{array}$ & $\begin{array}{l}18 \cdot 0 \\
12 \cdot 7 \\
25 \cdot 9 \\
22 \cdot 8 \\
26 \cdot 9 \\
26 \cdot 5 \\
19 \cdot 7\end{array}$ & $\begin{array}{l}- \\
- \\
- \\
- \\
- \\
-\end{array}$ \\
\hline & $\begin{array}{l}\text { Mean } \\
\text { Standard deviation }\end{array}$ & & $\begin{array}{l}0 \cdot 14 \\
0 \cdot 05\end{array}$ & $\begin{array}{l}0.04 \\
0.05\end{array}$ & $\begin{array}{r}14 \cdot 28 \\
3 \cdot 72\end{array}$ & $\begin{array}{l}3 \cdot 04 \\
0 \cdot 57\end{array}$ & $\begin{array}{l}3.92 \\
3.95\end{array}$ & $\begin{array}{r}54 \cdot 05 \\
7 \cdot 26\end{array}$ & $\begin{array}{r}21 \cdot 78 \\
5 \cdot 28\end{array}$ & - \\
\hline V & $\begin{array}{l}\text { C. gropengiesseri } \\
\text { C. magnoliae } \\
\text { C. versatilis } \\
\text { C. intermedia }\end{array}$ & $\begin{array}{l}\text { CBS } 156 \\
\text { CSIR-Y449 } \\
\text { CBS } 1731 \\
\text { CSIR-Y78 }\end{array}$ & $\begin{array}{l}0 \cdot 8 \\
0 \cdot 2 \\
0 \cdot 1 \\
0 \cdot 1\end{array}$ & $\begin{array}{l}0 \cdot 6 \\
0 \cdot 2 \\
0 \cdot 2 \\
0 \cdot 1\end{array}$ & $\begin{array}{l}5 \cdot 1 \\
8 \cdot 8 \\
6 \cdot 9 \\
2 \cdot 9\end{array}$ & $\begin{array}{l}11 \cdot 0 \\
15 \cdot 9 \\
22 \cdot 7 \\
15 \cdot 9\end{array}$ & $\begin{array}{l}8 \cdot 2 \\
2 \cdot 3 \\
5 \cdot 9 \\
4 \cdot 9\end{array}$ & $\begin{array}{l}70 \cdot 3 \\
71 \cdot 4 \\
62 \cdot 7 \\
73 \cdot 1\end{array}$ & $\begin{array}{l}- \\
- \\
- \\
-\end{array}$ & $\begin{array}{l}- \\
- \\
- \\
-\end{array}$ \\
\hline & $\begin{array}{l}\text { Mean } \\
\text { Standard deviation }\end{array}$ & & $\begin{array}{l}0 \cdot 30 \\
0.33\end{array}$ & $\begin{array}{l}0.27 \\
0.22\end{array}$ & $\begin{array}{l}5.92 \\
2 \cdot 51\end{array}$ & $\begin{array}{r}16 \cdot 37 \\
4 \cdot 80\end{array}$ & $\begin{array}{l}5 \cdot 32 \\
2 \cdot 44\end{array}$ & $\begin{array}{r}69 \cdot 37 \\
4 \cdot 59\end{array}$ & - & $\begin{array}{l}- \\
-\end{array}$ \\
\hline
\end{tabular}

* CBS, Centraalbureau voor Schimmelcultures, Yeast Division, Delft, The Netherlands; CSIR-Y, cultures obtained from Professor J. P. van der Walt, Pretoria, South Africa; NRRL, Northern Regional Research Laboratories, Peoria, Illinois, USA. 


\section{RESULTS AND DISCUSSION}

\section{Cellular long-chain fatty acid compositions}

Reproducible results were obtained when the 32 strains representing the genera Candida and Pichia were grown in triplicate under standard conditions. The mean fatty acid compositions are shown in Table 1 . The species were mainly characterized by the presence of palmitic acid (C16:0), palmitoleic acid (C16:1), stearic acid (C18:0), oleic acid (C18:1), linoleic acid (C18:2) and linolenic acid $(\mathrm{C} 18: 3)$. They could be divided into five groups according to the presence of linoleic acid ( $\mathrm{C} 18: 2)$ and linolenic acid $(\mathrm{C} 18: 3)$ and the mean percentage oleic acid (C18:1) (Table 1).

Group I, characterized by a pronounced high mean percentage linoleic acid (C18:2), the presence of linolenic acid $(\mathrm{C} 18: 3)$ and a low mean percentage oleic acid $(\mathrm{C} 18: 1)$ consisted of the single species Candida oregonensis.

Group II comprised 12 Candida species and five Pichia species; it was subdivided into three subgroups based on the ratios between oleic acid (C18:1), linoleic acid (C18:2) and linolenic acid (C18:3). Subgroup A comprised those species which had high mean percentages of oleic acid (C18:1) and linoleic acid (C18:2); subgroup B included species with a lower mean percentage of linoleic acid $(\mathrm{C} 18: 2)$ and a higher mean percentage of oleic acid $(\mathrm{C} 18: 1)$; and subgroup $\mathrm{C}$ comprised species which had much higher mean percentages of oleic acid (C18:1) and a lower mean percentage of linoleic acid (C18:2).

Group III, characterized by the absence of linolenic acid $(\mathrm{C} 18: 3)$ and a higher mean percentage of linoleic acid $(\mathrm{C} 18: 2)$ than oleic acid $(\mathrm{C} 18: 1)$, included $P$. etchellsii, $C$. maltosa and P. haplophila.

Group IV comprised species containing no linolenic acid $(\mathrm{C} 18: 3)$ and a higher mean percentage of oleic acid $(\mathrm{C} 18: 1)$ than linoleic acid $(\mathrm{C} 18: 2)$.

Group $\mathrm{V}$ included species which produced pronounced high mean percentages of oleic acid (C18:1) and no linoleic acid (C18:2) or linolenic acid (C18:3).

\section{Anamorph/teleomorph relations}

Several criteria should be met before an anamorph non-spore forming yeast is ascribed to a specific ascosporogenous teleomorph yeast. Anamorph/teleomorph relations are mainly based on morphological and physiological properties (Van Uden \& Buckley, 1970; Meyer et al., 1984). Other criteria, however, such as the coenzyme Q type (Phaff, 1984; Yamada \& Kondo, 1972), the degree of DNA relatedness (LethBak \& Stenderup, 1969; Nakase \& Komagata, 1971), cellular long-chain fatty acid compositions (Viljoen et al., 1987), proton magnetic resonance spectra (Manachini, 1979; Spencer \& Gorin, 1969), serological studies (Montrocher, 1982; Tsuchiya et al., 1965) and electrophoretic comparison of enzymes (Yamazaki \& Komagata, 1982), are all useful methods in correlating the relationships between imperfect and perfect yeasts. Most investigators agree that these phenotypic and genetic characteristics should be applied coordinately in order to correctly assign imperfect yeasts to perfect yeast forms.

In this study the similarities between 32 species, representing the genera Pichia and Candida, were determined on the basis of cellular long-chain fatty acid compositions, carbon-source assimilation, and the ability to utilize nitrate and to grow in a vitamin-free medium and at $37^{\circ} \mathrm{C}$. These characteristics were used coordinately in a new model (Fig. 1). The results obtained were compared with other criteria, viz. $\mathrm{G}+\mathrm{C}$ values, proton magnetic resonance spectra and enzyme studies, in order to evaluate possible new teleomorph/anamorph relations.

Anamorphic yeasts having a known perfect stage. The known anamorph/teleomorph-related yeasts are all closely positioned in Fig. 1 (enclosed in boxes), which indicates a high similarity in cellular long-chain fatty acid composition and other phenotypic characteristics.

(a) C. shehatae and $P$. stipitis. $C$. shehatae and $P$. stipitis, the species regarded as its perfect counterpart (Buckley \& Van Uden, 1967), have similar long-chain fatty acid compositions (Viljoen et al., 1987), carbon-source assimilation patterns ( $>90 \%$ similarity) and $\mathrm{G}+\mathrm{C}$ values $[42.5 \mathrm{~mol} \%$ for P. stipitis (Miranda et al., 1982) and $41.2 \mathrm{~mol} \%$ for C. shehatae (Nakase \& Komagata, 1971)], and both have coenzyme Q type 9 (Yamada \& Kondo, 1972). 


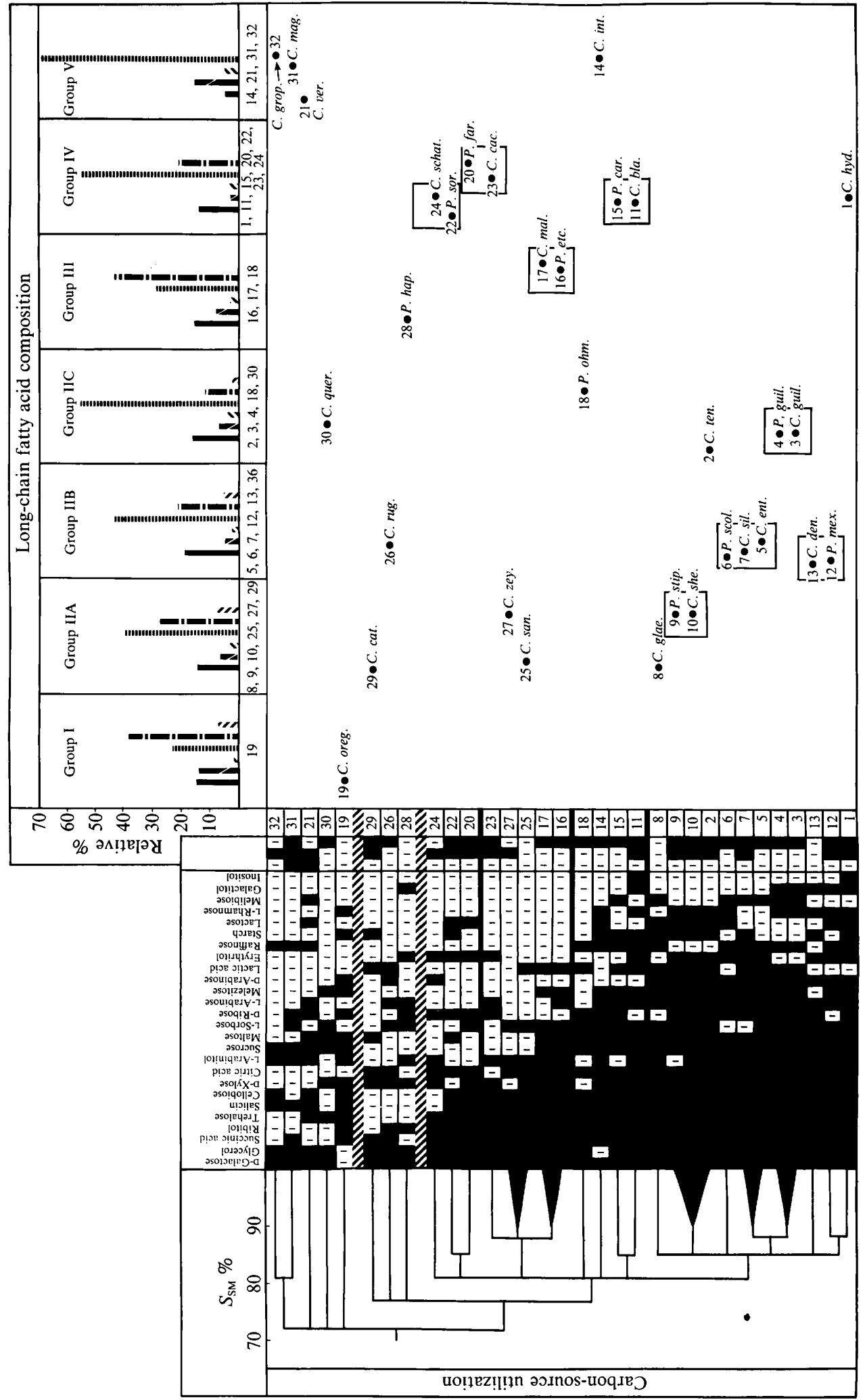


(b) C. guilliermondii and $P$. guilliermondii. C. guilliermondii and its assumed perfect state, $P$. guilliermondii (Van Uden \& Buckley, 1970) have similar long-chain fatty acid profiles (Table 1), carbon-source assimilation patterns ( $>90 \%$ similarity) and $\mathrm{G}+\mathrm{C}$ values $[44 \cdot 1-44.4 \mathrm{~mol} \%$ for C. guilliermondii (Nakase \& Komagata, 1971) and $44.4 \mathrm{~mol} \%$ for $P$. guilliermondii (Fuson et al., 1980)], and both have coenzyme Q type 9 (Yamada \& Kondo, 1972).

Yeasts having possible teleomorph/anamorph relations. (a) C. cacaoi and P. farinosa. These species produce similar long-chain fatty acid profiles (Fig. 1), have ovoid cells and moderate to well-developed pseudomycelium, and show $82 \%$ similarity in the assimilation of carbon sources. The two species are differentiated by the ability of $P$. farinosa to assimilate L-arabinose and Larabinitol (Fig. 1). They have similar G $+\mathrm{C}$ values [ $42.5 \mathrm{~mol} \%$ for $P$. farinosa and $41.7 \mathrm{~mol} \%$ for C. cacaoi (Meyer \& Phaff, 1972)] and proton magnetic resonance spectra (Gorin \& Spencer, 1970).

(b) C. maltosa and P. etchellsii. These species have similar long-chain fatty acid profiles (Table 1), morphology [short ovoidal cells of equal size, and well-developed pseudomycelium) (Meyer $e t$ al., 1984; Kurtzman, 1984)] and physiological properties ( $>90 \%$ similarity), and both have coenzyme Q type 9 (Yamada \& Kondo, 1972). According to the literature they are differentiated only by the ability of $C$. maltosa to assimilate L-arabinose and by the fermentation of galactose and trehalose (Meyer et al., 1984). A close relationship between these two yeasts is further indicated by their similar $\mathrm{G}+\mathrm{C}$ values [ $36.3 \mathrm{~mol} \%$ for C. maltosa (Nakase \& Komagata, 1971) and $38.5 \mathrm{~mol} \%$ for $P$. etchellsii (Nakase \& Komagata, 1970)].

Other Candida and Pichia species with similar long-chain fatty acid profiles. (a) C. blankii and $P$. carsonii. These two yeast species have almost identical long-chain fatty acid compositions (Table 1), show $85 \%$ similarity in the assimilation of carbon sources (Fig. 1), and produce similar cell shapes and abundant pseudohyphae. However, their $\mathrm{G}+\mathrm{C}$ values are very different [55.1 mol \% for C. blankii (Meyer et al., 1984) and $39.6 \mathrm{~mol} \%$ for $P$. carsonii (Kurtzman \& Smiley, 1979)].

(b) $C$. dendronema and $P$. mexicana. These species have similar long-chain fatty acid compositions (Table 1), and show $85 \%$ similarity in the assimilation of carbon sources (Fig. 1). Their G + C values are $42.2 \mathrm{~mol} \%$ for $P$. mexicana (Miranda et al., 1982) and $40.4 \mathrm{~mol} \%$ for $C$. dendronema (Stenderup et al., 1972).

(c) C. silvicultrix, C. entomophila and P. scolyti. These yeasts all have similar long-chain fatty acid profiles. C. silvicultrix and C. entomophila show $90 \%$ similarity in the assimilation of carbon sources and $85 \%$ similarity with $P$. scolyti. C. silvicultrix and $P$. scolyti both produce welldeveloped pseudomycelium with blastospores and ovoidal cells, of equal size. C. entomophila, on the other hand, produces true mycelium and cells of various shapes. There are major differences in G $+\mathrm{C}$ values, however, between $P$. scolyti $[40 \cdot 1 \mathrm{~mol} \%$ (Fuson et al., 1980)] and C. entomophila $[54.0 \mathrm{~mol} \%$ (Stenderup et al., 1972)] while C. silvicultrix has a lower value $[36.6 \mathrm{~mol} \%$ (Meyer et al., 1984)].

Fig. 1 (on facing page). Relationships between species of Candida and Pichia, arranged according to carbon source utilization (vertical scale, left) and long-chain fatty acid composition (horizontal scale, top). Species known or believed to have anamorph/teleomorph relationships are enclosed in boxes. 1. $C$. hyd., Candida hydrocarbofumarica; 2. C. ten., Candida tenuis; 3. P. guil., Pichia guilliermondii; 4. C. guil., Candida guilliermondii; 5. C. ent., Candida entomophila; 6. P. scol., Pichia scolyti; 7. C. sil., Candida silvicultrix; 8. C. glae., Candida glaebosa; 9. P. stip., Pichia stipitis; 10. C. she., Candida shehatae; 11. C. bla., Candida blankii; 12. P. mex., Pichia mexicana; 13. C. den., Candida dendronema; 14. C. int., Candida intermedia ; 15. P. car., Pichia carsonii; 16. P. etc., Pichia etchellsii; 17. C. mal., Candida maltosa; 18. P. ohm., Pichia ohmerii; 19. C. oreg., Candida oregonensis; 20. P. far., Pichia farinosa; 21. C. ver., Candida versatilis;22. P. sor., Pichia sorbitophila;23. C. cac., Candida cacaoi; 24 . C. schat., Candida schatavii; 25. C. san., Candida santamariae; 26. C. rug., Candida rugosa; 27. C. zey., Candida zeylanoides; 28. P. hap., Pichia haplophila; 29. C. cat., Candida catenulata; 30. C. quer., Candida quericitrusa; 31. C. mag., Candida magnoliae; 32. C. grop., Candida gropengiesseri. Key to lipid histograms:, C16:0 (palmitic acid); 工, C16:1 (palmitoleic acid); N, C18:0 (stearic acid); Uum, C18:1 (oleic acid); שIE, C18:2 (linoleic acid); $N$, C18:3 (linolenic acid). For the carbon-source utilization data, black blocks denote positive, and white spaces denote negative. 
(d) C. schatavii and $P$. sorbitophila. Both species are characterized by the absence of linolenic acid (C18:3), and have similar fatty acid profiles and carbon-source utilization patterns $(82 \%$ similarity).

(e) C. tenuis and $P$. guilliermondii. These species have closely similar long-chain fatty acid compositions (Table 1), coenzyme Q type 9 (Yamada \& Kondo, 1972), 85\% similarity in the assimilation of carbon sources (Fig. 1) and G $+\mathrm{C}$ values of $44.0 \mathrm{~mol} \%$ for C. tenuis (Stenderup \& LethBak, 1968) and $44.4 \mathrm{~mol} \%$ for $P$. guilliermondii. Furthermore, both species have ovoid to elongate cells of equal sizes and produce pseudomycelium and blastospores.

\section{Teleomorph relations}

Based on the results in Fig. 1 we detected two distinct groups in the genus Pichia. The first group comprises all the species with hat-shaped ascospores (Kurtzman, 1984), i.e. P. stipitis, $P$. scolyti, $P$. mexicana, $P$. guilliermondii and $P$. ohmeri, characterized by the presence of linolenic acid (C18:3). The second group comprises those species which form spheroidal ascospores (except $P$. haplophila) and are characterized by the absence of linolenic acid (C18:3), i.e. $P$. sorbitophila, $P$. farinosa, $P$. etchellsii, $P$. carsonii and $P$. haplophila (Muller et al., 1987).

\section{Anamorph relations}

The highly heterogeneous nature of the genus Candida is reflected in Fig. 1. Species without linoleic (C18:2) and linolenic (C18:3) acids (C. gropengiesseri, $C$. magnoliae, $C$. versatilis and $C$. intermedia) showed no resemblance to Pichia species on the basis of long-chain fatty acid compositions.

\section{CONCLUSIONS}

According to the results the following conclusions are drawn.

1. The coordinate use of long-chain fatty acid composition and other phenotypic characters, as illustrated in Fig. 1, provides a useful model to determine similarities between yeasts (i.e. anamorph/teleomorph, anamorph and teleomorph relations). Imperfect yeasts of the genus Candida and their known perfect forms were similar in their long-chain fatty acid compositions and in other phenotypic characteristics. These yeasts were in all cases closely positioned in the coordinate scheme (Fig. 1).

2. The following anamorph/teleomorph associations are proposed: $C$. cacaoi and P. farinosa, C. maltosa and $P$. etchellsii.

3. A correlation seems to exist between the coenzyme $Q$ type 9 Pichia species investigated which produce hat-shaped ascospores and the presence of linolenic acid ( $\mathrm{C} 18: 3)$, and the coenzyme Q type 9 Pichia species which produce spheroidal ascospores (except for $P$. haplophila) and the absence of linolenic acid (C18:3). More strains and species should however be investigated before any generalization is made.

4. The heterogeneous nature of the genus Candida is clearly illustrated in the coordinate scheme (Fig. 1).

The authors wish to thank Professor J. P. van der Walt of the CSIR, Pretoria, for supplying the yeasts, $\mathrm{Mr}$ P. J. Botes for assistance with gas chromatography, and Carol Viljoen for excellent secretarial assistance.

\section{REFERENCES}

Barnett, J. A., PAyne, R. W. \& Yarrow, D. (1983). Yeasts: Characteristics and Identification. Cambridge \& New York: Cambridge University Press.

BuCKLEY, H. R. \& VAN UdEN, N. (1967). Candida shehatae sp. n., a yeast associated with wooddestroying insects. Mycopathologia et mycologia applicata 32, 297-301.

Fuson, G. B., Price, C. W. \& Phaff, H. J. (1980). Deoxyribonucleic acid base sequence relatedness among strains of Pichia ohmeri that produce dimor- phic ascospores. International Journal of Systematic Bacteriology 30, 217-219.

Gorin, P. A. J. \& Spencer, J. F. T. (1970). Proton magnetic resonance spectroscopy - an aid in identification and chemotaxonomy of yeasts. $A d$ vances in Applied Microbiology 13, 25-89.

Kock, J. L. F., Lategan, P. M., Botes, P. J. \& VILJOEN, B. C. (1985). Developing a rapid statistical identification process for different yeast species. Journal of Microbiological Methods 4, 147-154. 
KREger-VAN RiJ, N. J. W. (editor) (1984). The Yeasts, a Taxonomic Study, 3rd edn. Amsterdam: Elsevier.

Kurtzman, C. P. (1984). Genus Pichia Hansen. In The Yeasts, a Taxonomic Study, 3rd edn, pp. 295-378. Edited by N. J. W. Kreger-van Rij. Amsterdam: Elsevier.

Kurtzman, C. P. \& Smiley, M. J. (1979). Taxonomy of Pichia carsonii and its synonyms $P$. vini and $P$. vini var. melibiosi: comparison by DNA reassociation. Mycologia 71, 658-662.

LethBAK, A. \& Stenderup, A. (1969). Deoxyribonucleic acid homology in yeasts. Genetic relatedness within the genus Candida. Journal of General Microbiology 59, 21-30.

MaNACHINI, P. L. (1979). DNA sequence similarity, cell wall mannans, and physiological characteristics in some strains of Candida utilis, Hansenula jadinil and Hansenula petersonii. Antonie van Leeuwenhoek 45, 451-463.

Meyer, S. A. \& PhafF, H. J. (1972). DNA base composition and DNA-DNA homology studies as tools in yeast systematics. In Yeasts, Models in Science and Technics, pp. 375-386. Edited by A. Kocková-Kratochvílová \& E. Minárik. Bratislava: Slovak Academy of Science.

Meyer, S. A., Ahearn, D. G. \& Yarrow, D. (1984). Genus Candida Berkhout. In The Yeasts, a Taxonomic Study, 3rd edn, pp. 585-844. Edited by N. J. W. Kreger-van Rij. Amsterdam: Elsevier.

Miranda, M., Holzschu, D. L., PhafF, H. J. \& Starmer, W. T. (1982). Pichia mexicana, a new heterothallic yeast from cereoid cacti in the North American Sonoran Desert. International Journal of Systematic Bacteriology 32, 101-107.

MoNTROCHER, R. (1982). Serological studies among sporogenous and asporogenous yeasts: antigenic structures of some Candida and related taxa. Cellular and Molecular Biology 28, 197-211.

Muller, H. B., Kock, J. L. F., Botes, P. J. \& LATEGAN, P. M. (1987). The cellular long-chain fatty acid composition of species representing the genus Pichia Hansen emend. Kurtzman. Systematic and Applied Microbiology 9, 280-283.

NaKase, T. \& Komagata, K. (1970). Significance of DNA base composition in the classification of yeast genus Pichia. Journal of General and Applied Microbiology 16, 511-521.

Nakase, T. \& Komagata, K. (1971). Significance of DNA base composition in the classification of the yeast genus Candida. Journal of General and Applied Microbiology 17, 259-279.

PhaFF, H. J. (1984). DNA, enzymes and cell wall. In
The Yeasts, a Taxonomic Study, 3rd edn, pp. 17-21. Edited by N. J. W. Kreger-van Rij. Amsterdam: Elsevier.

SoKal, R. R. \& SNEath, P. H. A. (1963). Principles of Numerical Taxonomy. London: W. H. Freeman.

SPENCER, J. F. T. \& GoRIN, P. A. J. (1969). Systematics of the genus Candida Berkhout: proton magnetic resonance spectra of the mannans and mannosecontaining polysaccharides as an aid in classification. Antonie van Leeuwenhoek 35, 33-44.

Stenderup, A. \& LethBak, A. (1968). Deoxyribonucleic acid base composition of some species within the genus Candida. Journal of General Microbiology 52, 231-236.

Stenderup, A., Meyer, S. A., LethBak, A. \& Christiansen, C. (1972). Taxonomy of Candida and Torulopsis. In Fermentation Technology Today. Proceedings of the IV International Fermentation Symposium, pp. 793-795. Edited by G. Terui. Osaka, Japan: Society of Fermentation and Technology.

TsuchiYa, T., Fukazawa, Y. \& KaWakita, S. (1965). Significance of serological studies on yeasts. $M y c o-$ pathologia et mycologia applicata 26, 1-15.

VAN UDEN, N. \& BUCKLEY, H. (1970). Genus Candida Berkhout. In The Yeasts, a Taxonomic Study, 2nd edn, pp. 893-1087. Edited by J. Lodder. Amsterdam: North-Holland.

Viljoen, B. C., Kock, J. L. F. \& Lategan, P. M. $(1986 a)$. Long-chain fatty acid composition of selected genera of yeast belonging to the Endomycetales. Antonie van Leeuwenhoek 52, 45-51.

VilJoen, B. C., Kock, J. L. F. \& LATEGAN, P. M. $(1986 b)$. The influence of culture age on the cellular fatty acid composition of four selected yeasts. Journal of General Microbiology 132, 1895-1898.

Viljoen, B. C., KoCK, J. L. F., MulleR, H. B. \& LATEGAN, P. M. (1987). Long-chain fatty acid compositions of some asporogenous yeasts and their respective ascosporogenous states. Journal of General Microbiology 133, 1019-1022.

WICKERHAM, L. J. (1951). Taxonomy of Yeasts. Technical Bulletin no. 1029, United States Department of Agriculture.

YamaDA, Y. \& Kondo, K. (1972). Taxonomic significance of coenzyme $Q$ system in yeasts and yeast-like fungi. In Yeasts, Models in Science and Technics, pp. 363-373. Edited by A. Kocková-Kratochvílová \& E. Minárik. Bratislava: Slovak Academy of Science.

YAMAZAKI, M. \& Komagata, K. (1982). Asporogenous yeasts and their supposed ascosporogenous states: an electrophoretic comparison of enzymes. Journal of General and Applied Microbiology 28, 119-138. 